\title{
Lead Residues in Milk and Blood of Cows at Selected Localities of Chittoor District of Andhra Pradesh, India
}

\section{Sujatha $\mathrm{K}^{*}$, Srilatha $\mathbf{C H}$, Chandrasekhar Rao TS and Sreenivasulu D}

Department of Veterinary Pathology, College of Veterinary Science, Sri Venkateswara Veterinary University, Tirupati, Andhra Pradesh, India

\begin{abstract}
The present study was planning to evaluate the concentrations of lead in blood and milk of crossbred cows reared in five different industrial areas in chittoor district of Andhra Pradesh. A total of 100 milk and 100 blood samples were collected from crossbred milk cows randomly in and around five factories, which were present in Chittoor District of Andhra Pradesh, India such as Batteries factory at Karakambadi, Nutrine factory and Sugar factory at chittoor and Lamco (Iron pipes) factory at Erpedu and Sugar factory at Puttur. The samples such as blood and milk were subjected for acid digestion method [1], then these samples were used for lead residual estimation by following method of Perkin-Elmer 3100 (USA) double beam atomic absorption spectrophotometer-meter with hallow cathode lamp of lead. The highest lead concentration was found in the blood of cows reared in and around Karakambadi area $(1.5 \mathrm{mg} / \mathrm{L})$ then followed by cows of Erpedu $(1.2 \mathrm{mg} / \mathrm{L})$, Chittoor (Nutrine factory) $(1 \mathrm{mg} / \mathrm{L})$, Puttur $(1.0 \mathrm{mg} / \mathrm{L})$ and Chittoor (Sugar factory) $(0.9 \mathrm{mg} / \mathrm{L})$. Significant correlation was noticed between high levels of increased blood lead and milk lead levels in cows that were at near in different factories. There was significant increase in blood lead concentration simultaneously increase in milk lead concentration. The increase blood lead in relation with increase milk lead might be due to the excretion of lead through milk increases with increase in blood lead level.
\end{abstract}

Keywords: Lead residues; Blood; Milk; Cattle; Correlelion

\section{Introduction}

Environmental pollution is a major global problem; industrial, agricultural, mining and natural process have resulted to the release of many toxic substances in to environment. These substances are readily transferred through food chains. Lead is one of the toxic metals; it is dangerous to most human body organs if the exposure exceeds tolerable levels [2]. Lead can affect individuals of any age, but it has a disproportionate effect on children because their behavioral patterns place them at higher risk of exposure to lead. Their bodies absorb a larger percentage of lead that they ingest and they exhibit lead toxicity of lower levels for exposure than adults [3]. Accumulation of lead produces damaging effects in the hemopoitic, renal and gastrointestinal systems [3].

The presence of lead in the environment is partially due to natural processes and anthropogenic sources [4,5]. But is mostly the result of industrial wastes [6]. Although atmospheric lead originates from a number of industrial sources, leaded gasoline appears to be a principle source of general environmental lead pollution. So, the heavy traffic flow of vehicles that burn gasoline with high lead content is the main cause of the high levels of lead in steet dusts and in air born particles [7].

The aim of the present study was to evaluate the concentrations of lead in blood and milk of crossbred cows, which are liable to contamination by lead. Also the investigation provided information about the concentration of lead in five different areas (Industrial) in Chittoor district of Andhra Pradesh.

\section{Materials and Methods}

\section{Study area and collection of blood and milk from cattle}

For estimation of lead residues in animals, those that are reared in different polluted/ industrial area were selected for milk and blood residual analysis.

A total of 100 milk and 100 blood samples were collected from crossbred milk cows randomly in and around five factories, which were present in Chittoor District of Andhra Pradesh, India such as Batteries factory at Karakambadi, Nutrine factory and Sugar factory at chittoor and Lamco (Iron pipes) factory at Erpedu and Sugar factory at Puttur.

Ten $\mathrm{ml}$ of raw milk was collected into a sterile and acid washed vials and blood was collected into heparinized vials and were collected randomly and packed separately and stored at $-20^{\circ} \mathrm{C}$ until analysis.

The samples such as blood and milk were subjected for acid digestion method [1], then these samples were used for lead residual estimation by following method of Perkin-Elmer 3100 (USA) double beam atomic absorption spectrophotometer-meter with hallow cathode lamp of lead.

Statistical differences between localities were determined by oneway analysis of variance (ANOVA).

\section{Results}

The mean values of pooled blood and milk lead levels in cows found near to different factories of Chittoor District in Andhra Pradesh such as batteries factory (Karakambadi), Nutrine factory (Chittoor), Sugar factory (Chittoor), Sugar factory (Puttur) and Lamco factory (Erpedu) were $1.50,1.00,0.90,1.00,1.20$ and $1.10,0.90,0.70,0.80,1.00(\mathrm{mgs} / \mathrm{L})$ respectively and are shown in Table 1 and Figures 1 and 2. The highest blood and milk lead content was observed in animals reared near batteries factory then followed by Lamco factory when compared to other factories as mentioned in Chittoor district.

*Corresponding author: Sujatha K, Department of Veterinary Pathology, College of Veterinary Science, Sri Venkateswara Veterinary University, Tirupati-517 502, Andhra Pradesh, India, Tel: +919440973609; E-mail: karamalasujatha@gmail.com

Received March 28, 2016; Accepted June 17, 2016; Published June 22, 2016

Citation: Sujatha K, Srilatha CH, Rao CTS, Sreenivasulu D (2016) Lead Residues in Milk and Blood of Cows at Selected Localities of Chittoor District of Andhra Pradesh, India. J Vet Sci Technol 7: 353. doi:10.4172/2157-7579.1000353

Copyright: ( 2016 Sujatha K, et al. This is an open-access article distributed under the terms of the Creative Commons Attribution License, which permits unrestricted use, distribution, and reproduction in any medium, provided the original author and source are credited. 


\begin{tabular}{|c|c|c|c|c|c|}
\hline Location & $\begin{array}{c}\text { Karakambadi } \\
\text { (Batteries } \\
\text { factory) }\end{array}$ & $\begin{array}{c}\text { Nutrine } \\
\text { factory } \\
\text { (Chittoor) }\end{array}$ & $\begin{array}{c}\text { Sugar } \\
\text { factory } \\
\text { (Chittoor) }\end{array}$ & $\begin{array}{c}\text { Sugar } \\
\text { factory } \\
\text { (Puttur) }\end{array}$ & $\begin{array}{c}\text { Lamco } \\
\text { factory } \\
\text { (Erpedu) }\end{array}$ \\
\hline $\begin{array}{c}\text { Blood } \\
\text { M } \pm \text { SE }\end{array}$ & $1.50 \pm 0.029$ & $1 \pm 0.03$ & $0.9 \pm 0.025$ & $1 \pm 0.05$ & $1.2 \pm 0.045$ \\
\hline $\begin{array}{c}\text { Milk } \\
\text { M } \pm \text { SE }\end{array}$ & $1.10 \pm 0.03$ & $0.9 \pm 0.036$ & $0.7 \pm 0.05$ & $0.8 \pm 0.035$ & $1 \pm 0.035$ \\
\hline
\end{tabular}

Table 1: Lead residues (mgs/L) in blood and milk samples of cattle from different localities.

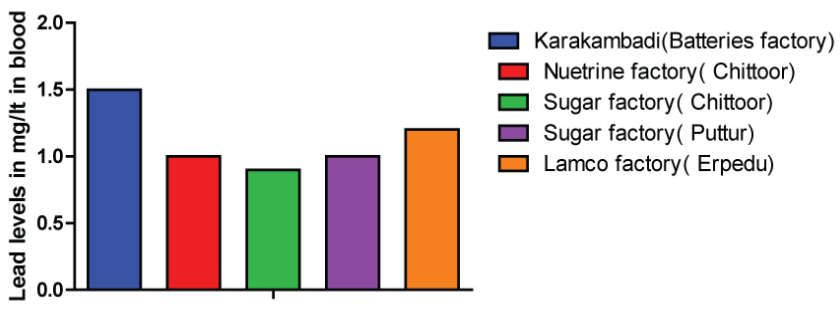

Location of blood collection

Figure 1: Mean values of Lead levels (mgs/L) in blood samples of cattle.

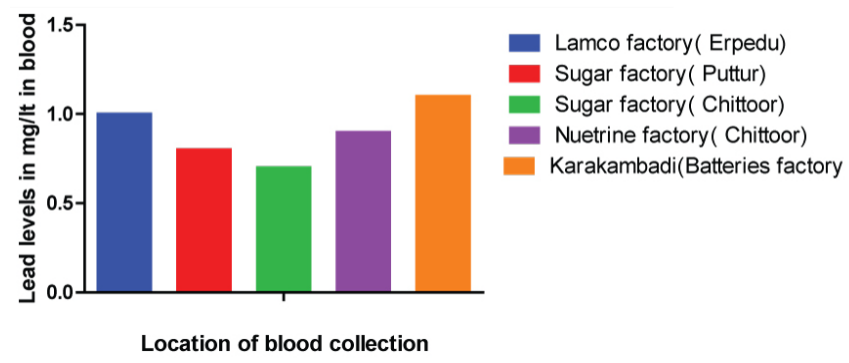

Figure 2: Mean values of Lead levels (mgs/L) in milk samples of cattle.

\section{Discussion}

In the present epidemiological study, blood and milk samples were collected from five different factory areas of Chittoor district in Andhra Pradesh and the areas were Karakambadi (batteries factory), Chittoor (Nutrine factory), Chittoor (Sugar factory), Puttur (Sugar factory) and Erpedu (Lamco factory). These samples were analyzed for lead levels. The highest lead concentration was found in the blood of cows reared in and around Karakambadi area $(1.5 \mathrm{mg} / \mathrm{L})$ then followed by cows of Erpedu (1.2 mg/L), Chittoor (Nutrine factory) $(1 \mathrm{mg} / \mathrm{L})$, Puttur $(1.0 \mathrm{mg} / \mathrm{L})$ and Chittoor (Sugar factory) $(0.9 \mathrm{mg} / \mathrm{L})$. Swarup et al. [8] reported highest blood lead concentration in buffaloes in industrial area of Ghaziabad $(0.58 \pm 0.87 \mathrm{ppm})$ followed by cows from urban area of Delhi $(0.58 \pm 0.37 \mathrm{ppm})$.

The highest lead concentration in blood of cows reared in and around batteries factory might be due to the industrial waste that was channeled into water canals or ponds. So heavy contamination might have taken place in soil as well as water and fodder. The second highest concentration of lead was found in Lamco factory (Iron ores) at Erpedu due to industrial pollution in and around factory. The next highest values found in Chittoor Nutrine factory area because it was found in center of Urban area, so traffic pollution and factory pollution might be the reason for high lead concentrations. The other two areas Puttur (Sugar factory) and Chittoor (Sugar factory) low level of lead was noticed in cows blood when compared to above mentioned areas and this might be due to pollution that has occurred due to factory only and these factories placed faraway from Urban area.
The highest lead levels were observed in milk of cows found in Karakambadi area $(1.10 \mathrm{mg} / \mathrm{L})$ when compared to other industrial areas as mentioned. The second highest lead level in cows of Erpedu area $(1.0 \mathrm{mg} / 1 \mathrm{~L})$ followed by Chittoor (Nutrine factory) $(0.9 \mathrm{mg} / \mathrm{L})$, Puttur (Sugar factory) $(0.80 \mathrm{mg} / \mathrm{L})$. This might be due to factory placed faraway from urban area and here the pollution has taken place form factory waste and emission only and no other source of pollution. Valiukenaite et al. [9] analyzed raw milk from 15 districts in Lithuania. The mean lead concentration in winter milk samples were $0.47 \mu \mathrm{g} / \mathrm{kg}$ $(0.17-1 \mu \mathrm{g} / \mathrm{kg})$ and in summer $0.54 \mu \mathrm{g} / \mathrm{kg}(0.06-1.76 \mu \mathrm{g} / \mathrm{kg})$.

In the present study lead concentration in blood and milk in different areas were higher than the normal permissible level in cattle. So these higher values in turn cause adverse effects on animal health as well as human beings.

Significant correlation was noticed between high levels of increased blood lead and milk lead levels in cows that were at near in different factories. There was significant increase in blood lead concentration simultaneously increase in milk lead concentration. Swarp et al. [10] recorded the highest blood lead level in animals that were around leadzinc smelting factories followed by Zinc smelter, aluminum processing unit and steel manufacturing plant. The highest milk lead level ( 0.84 $\pm 0.11 \mathrm{mg} / \mathrm{ml}$ ) was detected in animals reared at lead-Zinc smelting unit followed by aluminum and steel processing unit. Oskarsson et al. [11] observed transfer of lead to milk in cattle in relation to blood lead levels and the uptake of lead in edible tissues in an accidental exposure that resulted from the licking of burnt storage batteries. Two weeks after exposure the milk and blood lead concentration was $0.08 \pm 0.04$ $\mathrm{mg} / \mathrm{kg}$ and $0.36 \pm 0.04 \mathrm{mg} / \mathrm{kg}$ respectively in six cows. Swarup et al. [8] estimated the samples of animal feed and blood from cattle and buffaloes of the Urban area of Delhi, Industrial area of Ghaziabad and verges highway for residual levels and observed highest concentration of blood lead was found in buffaloes in Ghaziabad $(0.58 \pm 0.87 \mathrm{ppm})$ followed by cows from Delhi $(0.58 \pm 0.037)$. The highest lead conc. was found in hay samples from Delhi (140.05 ppm DM basis) followed by grasses $(6.38 \pm 1.29 \mathrm{ppm})$ from Ghaziabad industrial area. The increase blood lead in relation with increase milk lead might be due to the excretion of lead through milk increases with increase in blood lead level.

Cattle and other animals serve as bio-indicators of environmental contamination with heavy metals [12]. The presence of lead in the tested samples of animal serves as an indication that the environment where these animals grazed before they were purchased for raring was contaminated with lead. Consumption of milk of these animals may pose a serious health problem to man especially children $<5$ years old as a result of bioaccumulation of lead in the body tissues. This however varies among individuals and depends on duration of exposure [13].

\section{References}

1. Kolmer JA, Spaudling EH, Robinson HW (1951) Approved lab technique. 5th edn. Appleton Century Crafts Inc., New York, USA, pp: 1090-1091.

2. Baht RV, Moy GG (1997) Monitoring and assessment of dietary exposure to chemical contaminants. World Health Stat Q 50: 132-149.

3. Correia PRM, Oliveira E, Oliveira PV (2000) Simultaneous determination of Cd and $\mathrm{Pb}$ in foodstuffs by electrothermal atomic absorption spectrometry. Anal Chim Acta 405: 205-211

4. Fernandes AG, Ternero M, Barragan GF (2000) An approach to characterization of urban air born particles through heavy metal speciation. Chemosphere 2 : 123-136.

5. Beavington F, Cawse PA, Wakenshaw A (2004) Comparative studies of atmospheric trace elements: improvements in air quality near a copper smelter. Sci Total Environ 332: 39-49. 
Citation: Sujatha K, Srilatha CH, Rao CTS, Sreenivasulu D (2016) Lead Residues in Milk and Blood of Cows at Selected Localities of Chittoor District of Andhra Pradesh, India. J Vet Sci Technol 7: 353. doi:10.4172/2157-7579.1000353

6. Khillare PS, Balachandran S, Meena BR (2004) Spatial and temporal variation of heavy metals in atmospheric aerosol of Delhi. Environ Monit Assess 90: $1-21$.

7. Durands ML, Aragon SR (1982) Atmospheric lead in downtown Guatemata city. Environ Sci Technol 16: 20-23

8. Swarup D, Dwivedi SK, Pandey NN, Sharma MC (1993) Lead in feed and blood of bovines in varied environmental localities. Ind J Vet Res 2: 34-37.

9. Valiukenaite R, Stankeviciene M, Stankevicius H, Skibniewska KA (2006) Lead and Cadmium levels in raw Cow's Milk in Lithuania determined by inductively coupled plasma sector field mass spectrometry. Pol J Food Nutr Sci 15: 243-246.
10. Swarp D, Patral RC, Naresh RKP, Shekhar P (2005) Blood lead levels in lactating cows reared around polluted localities: transfer of lead into milk. Science Total Environment 347: 106-110.

11. Oskarsson A, Jorhem L, Sundberg J, Nilsson NG, Albanus L (1992) Lead poisoning in cattle--transfer of lead to milk. Sci Total Environ 111: 83-94.

12. Kosnett MJ, Wedeen RP, Rothenberg SJ, Hipkins KL, Materna BL, et al. (2007) Recommendations for medical management of adult lead exposure. Environ Health Perspect 115: 463-471.

13. Miranda M, Benedito JL, Blanco-Penedo I, López-Lamas C, Merino A, et al. (2009) Metal accumulation in cattle raised in a serpentine-soil area: relationship between metal concentrations in soil, forage and animal tissues. J Trace Elem Med Biol 23: 231-238. 